\title{
Cattle preferences for a hybrid grass: chemical and morpho- logical relationships
}

DOREEN R. TRUSCOTT AND PAT O. CURRIE

\section{Abstract}

Forty-six clonal lines of a hybrid cross between Pseudoroegneria spicata [Pursh.] Seribn. and Smith $\times$ Elytrigia repens [L.] Beauv. were used to evaluate the infuence of various chemical and morphological characteristics on cattle preference. Variables examined included total carbohydrates as well as several individual sugars, silica, nitrogen, moisture, leaf and growth form, phenology and plant height. In 3 of 4 trials, over $60 \%$ of the variation in preference as measured by bite counts was accounted for in the analyses. However, dominant factors controlling preference varied from trial to trial. Predictive equations developed for each trial $(N=46)$ produced $R^{2}$ values which ranged from 0.53 to 0.81 . Common variables that influenced predictions included basal area, phenology, nitrogen, leaf score, and digestibility. Basal area was the most important single variable positively related to preference with an $R^{2}$ value of 0.70 over all trials. Individual sugar analyses were not significantly $(P>0.05)$ related to bites for most trials but became important from mid-June to mid-July. Equations which included sugar analyses $(n=20)$, accounted for 73 to $87 \%$ of the variation in bites. However, basal area and phenology were the dominant variables in these equations. Therefore no single equation could be used to accurately predict preferences.

Key Words: bluebunch wheatgrass, quackgrass, forage, animal preference hybrid grass

To make rapid progress in forage breeding programs, plant geneticists need techniques to measure not only intake and digestibility but also animal preference for plants since preference may be important in assuring animals will accept new plant selections. Several techniques have been developed to measure preference (Krueger 1972). However, little work has been done on the prediction of livestock preference for forage plants.

Avoidance or rejection of plants by animals is often caused by the presence of certain secondary chemical constituents or adversive surface characteristics (Martin 1969). Identification of other factors which contribute to overall desirability is difficult because of: (1) inconsistencies in grazing trials resulting from animal and plant variation, (2) limited knowledge of the mechanisms involved in plant selection by livestock, and (3) poor correlations between standard chemical assays and observations on selections.

Most studies of relationships between chemical constitution of a plant and animal preference have focused on general analyses or large chemical groups such as protein, fiber, in vitro digestibility, etc. Little attention has been paid to the individual chemicals in a plant or to their constituent compositions. For example, a change in the basic structural form of a chemical compound altered insect

\footnotetext{
Authors are research associate, MAES, and range scientist, respectively, USDA, Agricultural Research Service, at the Fort Keogh Livestock and Range Research Laboratory, Route 1, Box 2021, Miles City, Montana 59301.

This research is a contribution from the USDA, Agricultural Research Service, Fort Keogh Livestock and Range Research Laboratory (USDA-ARS) and the Montana Agricultural Experiment Station (MAES). Contribution J1977.

The research reported was also in partial fulfillment of a graduate degree by D.R. Truscott at Colorado State University, Fort Collins. The authors wish to gratefully acknowledge Drs. W.A. Laycock, K.H. Asay, G.V. Richardson, and B.W. Knapp, USDA-ARS, and Drs. C.D. Bonham, N.A. Daugherty, and E.T. Bartlett, CSU, for their support and contributions.

Manuscript accepted 12 July 1988.
}

taste response (Chapman and Blaney 1979). Arnold (1981), however, questioned the value of any attempt to identify "palatability factors" due to the complexity of the matrix of plant and animal factors involved. Thus, there is not uniform agreement on solving the chemical-animal preference factor, but it is worthy of further investigations.

This study examined factors that could possibly predict livestock preferences and some component chemical compounds which comprise the larger chemical groups. It was hypothesized that individual sugar proportions would be more closely related with preference than gross carbohydrate assays examined in previous research. Comparisons of animal response to the plants' chemical and physical composition were made to determine if these factors could be used alone or in combination to predict selective preferences.

\section{Materials and Methods}

A study was initiated in the spring of 1981 to determine preference differences between 46 clonal lines of bluebunch wheatgrass (Pseudoroegneria spicata [Pursh] and Scribn and Smith) $\times$ quackgrass (Elytrigia repens [L.] Beauv.) ${ }^{1}$, referred to as the RS hybrid, (Asay and Dewey 1981) and to evaluate chemical or morphological factors contributing to those differences. Single plant plots of the 46 lines were arranged within each of 10 replications on $1.0-\mathrm{m}$ centers in 2 rows of 23 plants each in a randomized complete block design. Eight gentle yearling Hereford steers with an average initial weight of $200 \mathrm{~kg}$ were used to evaluate relative preferences for the 46 cloned RS hybrid plants (Truscott and Currie 1987).

Replications 1 to 5 were fenced separately from replications 6 to 10 and are hereafter referred to as pastures 1 and 2, respectively. Four trials were conducted in each pasture beginning 15 May 1981 in pasture 1 and continued at 2-week intervals in alternate pastures through 28 August.

Two days prior to each grazing trial, randomly selected tillers within each line were clipped to a $10-\mathrm{cm}$ stubble height. This sample (approximately $60 \mathrm{~g} \mathrm{DM}$ ), composited across replications, was divided into 3 independent samples immediately after clipping. One subsample was immediately frozen on site using dry ice, lyophilized, and ground to pass a 1.0-mm screen in a cyclone mill. It was then stored in a desiccator until analyzed. A second subsample was transported at near $0^{\circ} \mathrm{C}$ until weighed, and dried at $100^{\circ} \mathrm{C}$ for $1 / 2$ hour followed by $70^{\circ} \mathrm{C}$ for 24 hours and reweighed for determination of moisture content. The third subsample was dried similar to the second and used for other analyses. Dry matter digestibilities were determined by both rumen inoculum (Tilley and Terry 1963) and bacterial cellulase techniques (Goto and Minson 1977). Total nonstructural carbohydrates (TNC), total soluble carbohydrates (TSC), nitrogen, and phosphorus were colorimetri-

\footnotetext{
'Nomenclature follows that proposed by Dr. D.R. Dewey (1984), Crops Research Laboratory, Logan, Utah. Previous nomenclature was Agropyron spicatum for bluebunch wheatgrass and Agropyron repens for quackgrass.
} 
cally determined using a Technicon Autoanalyzer ${ }^{2}$ (Technicon $1977 \mathrm{a}, \mathrm{b})$. Total silica was measured colorimetrically following procedures described by Fox et al. (1969). Ash was determined as the residue remaining after heating at $550^{\circ} \mathrm{C}$ for 12 hours. Total reducing sugars (Somogyi 1952) of both water and $.2 \mathrm{~N}_{2} \mathrm{SO}_{4}$ hydrolysates (Smith et al. 1964) were measured using freeze-dried samples. Hydrolysis curves were made for both extractions to establish maximum yield times and appropriate acid concentrations. Fructose and glucose concentrations were determined from these hydrolysates using trimethylsilyl (TMS) ester derivatives on a gas chromatograph (Sweeley et al. 1963). Supelco's HTP Sylon ${ }^{3}$ was used to silylate. Inositol was the internal standard added to each sample $(500 \mu \mathrm{g} / \mathrm{ml})$ prior to silylation. Glucose and fructose standard solutions were used to check completeness of derivitization. Alditol acetate derivatives of the acid hydrolysate were used to determine quantities of other sugars present in addition to the glucose and fructose (Bittner et al. 1980). The method was modified and an excess of acetic anhydride was used, $1.5 \mathrm{ml}$ rather than $0.25 \mathrm{ml}$, to eliminate the need for repeated evaporations over methanol. Inositol was the internal standard, and derivitization precision was determined using a 7-sugar standard solution (rhamnose, fucose, arabinose, xylose, mannose, galactose, glucose). These gas chromatograph assays were done on the 10 most preferred and 10 least preferred clonal lines from each trial as established by relative preference rankings in the grazing trials (Truscott \& Currie 1987).

Physical measurements and rated observations of the plants were also made prior to grazing trials. Included were plant height, basal area, phenology, leaf type, and growth form. Phenology was scored from 1 to 15 , as follows: $1-3$, early to late leaf; $4-6$, early to late boot; 7-8, early to late anthesis; 9-11, early to late dough; and $12-15$, seed ripe to dormancy. An added percentage estimate (0.5 to 0.9 ) for the proportion of the plant at that stage was included. Leaf score was based on a 9-point scale, 1 = limp, droopy leaves and 9 = stiff, erect leaves. Growth form was rated on a 9-point scale, 1 = bunchy growth form and $9=$ rhizomatous, low spreading form.

\section{Statistical Analysis}

Individual bite count data were summed over animals and replications to obtain total bites/clonal hybrid line. Individual plant line data, which included phenology, basal areas and the various scores, were handled in a similar manner. Chemical data were collected from composite samples of lines over replications and thus it was compatible with the bite count and plant data. Percent fructose was calculated from the TMS assay. The amount of fructose was divided by the sum of fructose and glucose and then multiplied by 100. Absolute amounts of the other sugars were used in the analyses. A one-way analysis of variance for sugars used rank (top $10=1$, bottom $10=2$ ) as the main effect.

Rank-order correlation coefficients (Spearman's Rho) were used to measure relationships of the various measurements to bite count and utilization data (Siegel 1956). Multiple regression analyses were used to develop potential prediction equations for animal preferences; i.e., the all-possible-subsets regression analysis employed Mallow's $C p$ values to select the "best" equations (Daniel and Wood 1971).

\section{Results and Discussion}

\section{Plant Morphology and Phenology}

Mean plant widths and lengths varied between trials in a random fashion (Table 1). Mean plant heights reflected the influence of the clipping and grazing treatments. In trial 1, the means of 66 and 88 $\mathrm{cm}$ were greater than the mean of $\bar{x}=45 \mathrm{~cm}$ for subsequent trials as

\footnotetext{
${ }^{2}$ Mention of a trade name does not constitute endorsement by USDA-ARS, but is provided for the convenience of the reader.

3Supelco Inc., Supelco Park, Bellefonte, Pennsylvania.
}

Table 1. Trial and pasture means of morphologieal, phenologieal, and chemical data. 1981 trtak.

\begin{tabular}{|c|c|c|c|c|c|c|c|c|}
\hline \multirow{2}{*}{$\begin{array}{l}\text { Plant and } \\
\text { Chemical } \\
\text { Measurements }\end{array}$} & \multicolumn{2}{|c|}{$\begin{array}{c}\text { Trial l } \\
\text { Pasture }\end{array}$} & \multicolumn{2}{|c|}{$\begin{array}{c}\text { Trial } 2 \\
\text { Pasture }\end{array}$} & \multicolumn{2}{|c|}{$\begin{array}{l}\text { Trial } 3 \\
\text { Pasture } \\
\end{array}$} & \multicolumn{2}{|c|}{$\begin{array}{c}\text { Trial } 4 \\
\text { Pasture }\end{array}$} \\
\hline & 1 & 2 & 1 & 2 & 1 & 2 & 1 & 2 \\
\hline $\begin{array}{l}\text { Height, cm } \\
\text { Width, cm } \\
\text { Length, cm } \\
\text { Phenology, } \\
\text { scorel } \\
\text { Leaf score } \\
\text { Growth form, } \\
\text { scorel }\end{array}$ & $\begin{array}{l}4.7 \\
6.0 \\
5.4\end{array}$ & $\begin{array}{l}88 \\
52 \\
59\end{array}$ & $\begin{array}{l}50 \\
47 \\
56\end{array}$ & $\begin{array}{l}48 \\
56 \\
57\end{array}$ & $\begin{array}{l}59 \\
55 \\
61\end{array}$ & $\begin{array}{l}40 \\
57 \\
56\end{array}$ & $\begin{array}{l}37 \\
51 \\
52\end{array}$ & $\begin{array}{l}34 \\
54 \\
61\end{array}$ \\
\hline $\begin{array}{l}\text { TNC }^{2}, \% \\
\text { TSC } 3 \text {, \% } \\
\text { Nitrogen, \% } \\
\text { Phosphorus, \% } \\
\text { Silica, \% } \\
\text { Cellulase in } \\
\text { vitro digesti- } \\
\text { bility, } \%\end{array}$ & $\begin{array}{l}30 \\
10 \\
3.1 \\
0.29 \\
2.5\end{array}$ & $\begin{array}{l}28 \\
8.3 \\
2.3 \\
0.24 \\
2.7\end{array}$ & $\begin{array}{l}25 \\
9.3 \\
3.2 \\
0.26 \\
3.8\end{array}$ & $\begin{array}{l}24 \\
9.4 \\
3.4 \\
0.26 \\
4.2\end{array}$ & $\begin{array}{l}26 \\
8.3 \\
2.8 \\
0.25 \\
2.9\end{array}$ & $\begin{array}{l}30 \\
8.5 \\
2.8 \\
0.23 \\
3.2\end{array}$ & $\begin{array}{l}29 \\
8.7 \\
2.2 \\
0.20 \\
4.6\end{array}$ & $\begin{array}{l}28 \\
10 \\
2.6 \\
0.22 \\
6.2\end{array}$ \\
\hline $\begin{array}{l}\text { Rumen in vitro } \\
\text { digesti- } \\
\text { bility, \% } \\
\text { Ash, \% } \\
\text { Moisture, \% } \\
\text { Reducing sugar, } \\
\text { acid, \% }\end{array}$ & $\begin{array}{l}80 \\
10 \\
75 \\
9.0\end{array}$ & $\begin{array}{l}72 \\
10 \\
73\end{array}$ & $\begin{array}{l}81 \\
11 \\
72\end{array}$ & $\begin{array}{l}80 \\
12 \\
58\end{array}$ & $\begin{array}{l}72 \\
11 \\
64\end{array}$ & $\begin{array}{l}75 \\
10 \\
66\end{array}$ & $\begin{array}{l}67 \\
12 \\
60\end{array}$ & $\begin{array}{l}66 \\
14 \\
62\end{array}$ \\
\hline
\end{tabular}

IPhenology score scale was 1 to 15 and 1 to 9 for leaf and growth form. ${ }^{2}$ TNC = total non-structural carbohydrate.

${ }^{3}$ TSC = total soluble carbohydrate.

a result of not being previously grazed. Phenology scores were also influenced by the clipping and grazing treatments. Scores for leaf and plant growth form showed little variability throughout the study.

\section{Chemical Composition}

Percent nitrogen ranged from 2.2 to $3.4 \%$ (Table 1). Mean digestibility (rumen in vitro) of the hybrids ranged from $81 \%$ in mid-June to a low of $66 \%$ in trial 4 (August 13-28). Generally, differences between the plants with respect to most of the measurements taken were greatly reduced during trial 2 (15 June to 15 July) because of the ideal growth conditions which existed at that time. Nonstructural carbohydrates showed a characteristic drop during the early season then a rise again as the season progressed (Mcllvanie 1942). Reducing sugar assay measures a similar component as the nonstructural carbohydrate assay but is a much milder extraction procedure and thus extracts fewer cell wall sugars and resulted in correspondingly lower values. Percent reducing sugars, moisture, and percent phosphorus generally decreased with advancing season.

\section{Chemical and Morphological Relationships}

Rank-order correlations between bite counts and all $1981 \mathrm{chem}$ ical, morphological, and phenological data showed several significant $(P<0.05)$ positive and negative relationships (Table 2). However, few were considered large enough to be biologically important $(r>0.60$ or $<-0.60$ ). These relationships were observed to change substantially from trial to trial. Changes reflected seasonality. Significant relationships in trial 1 were different from those in other trials. Consequently, these plants were grazed at a more advanced stage phenologically and were able to attain greater height than plants in subsequent trials.

Correlations between plant basal area and bites were consistently strong and ranged from 0.61 to 0.77 during trials 1 (15 
Table 2. Spearman's correlation coeficients of bite counts wh selected chemical and morpholodical variables during the 1981 triak, $n=46.1$

\begin{tabular}{|c|c|c|c|c|c|c|c|c|}
\hline \multirow[b]{2}{*}{ Bites With: } & \multicolumn{8}{|c|}{ Trial-Pasture } \\
\hline & $1-1$ & $1-2$ & $2-1$ & $2-2$ & $3-1$ & $3-2$ & $4-1$ & $4-2$ \\
\hline $\begin{array}{l}\text { Height, cm } \\
\text { Area }^{2}\end{array}$ & $\begin{array}{r}-.44^{*} \\
.61^{*}\end{array}$ & $\begin{array}{r}-.23^{*} \\
.65^{*}\end{array}$ & $\begin{array}{l}.40^{*} \\
.27\end{array}$ & $\begin{array}{l}.47^{*} \\
.06\end{array}$ & $\begin{array}{l}.08 \\
.70^{*}\end{array}$ & $\begin{array}{l}.36^{*} \\
.77^{*}\end{array}$ & $\begin{array}{l}.36^{*} \\
.68^{*}\end{array}$ & $\begin{array}{l}.38^{*} \\
.74^{*}\end{array}$ \\
\hline $\begin{array}{l}\text { CIUD }^{3} \\
\text { RIUD }^{4}\end{array}$ & $\begin{array}{l}.42^{*} \\
.28\end{array}$ & $\begin{array}{l}.63^{*} \\
.65^{*}\end{array}$ & $\begin{array}{l}.30^{*} \\
.20\end{array}$ & $\begin{array}{l}.29 \\
.21\end{array}$ & $\begin{array}{l}.40^{*} \\
.32^{*}\end{array}$ & $\begin{array}{l}.21 \\
.11\end{array}$ & $\begin{array}{c}.36 * \\
-.13\end{array}$ & $\begin{array}{l}.36 * \\
.32^{*}\end{array}$ \\
\hline Leaf score & $-.35^{*}$ & -.17 & .06 & $-.52^{\star}$ & $-.30^{\circ}$ & -.07 & .21 & -.23 \\
\hline $\begin{array}{l}\text { Nitrogen, \% } \\
\text { Phosphorus, \% } \\
\text { Silica, \% } \\
\text { Phenology score } \\
\text { TNCs }\end{array}$ & $\begin{array}{c}.43^{*} \\
.17 \\
.00 \\
-.33^{*} \\
-.43^{*}\end{array}$ & $\begin{array}{c}.10 \\
.08 \\
-.46^{*} \\
-.17 \\
-.26\end{array}$ & $\begin{array}{r}.11 \\
.24 \\
-.21 \\
.08 \\
-.17\end{array}$ & $\begin{array}{r}.05 \\
.16 \\
-.27 \\
.20 \\
-.50^{*}\end{array}$ & $\begin{array}{r}.38 * \\
.09 \\
-.08 \\
-.06 \\
-.16\end{array}$ & $\begin{array}{c}.38^{\star} \\
.06 \\
.13 \\
-.32^{*} \\
-.36^{*}\end{array}$ & $\begin{array}{l}.40^{*} \\
.34^{*} \\
.34^{*} \\
-.07 \\
-.48^{*}\end{array}$ & $\begin{array}{l}.37 * \\
.47 * \\
.03 \\
-.37 * \\
-.23\end{array}$ \\
\hline $\begin{array}{l}\text { TSC }^{6} \\
\text { Nonsignificant } \\
\text { Ash } \\
\text { Nonsignificant } \\
\text { Moisture } \\
\text { Nonsignificant }\end{array}$ & & & & & & & & \\
\hline
\end{tabular}

'Correlation coefficients $>0.60$ or $<-0.60$ were considered biologically important.

${ }^{2}$ Area $=$ width $(\mathrm{cm}) \times$ length $(\mathrm{cm})$ of plant base or crown.

${ }^{3}$ CIUD = cellulase in vitro digestibility.

"RIUD = rumen in vitro digestibility.

TTNC = total non-structural carbohydrates.

'TSC = total soluble carbohydrates.

- Significant, $P<0.05$.

May-15 June), 3(15-28 July), and 4(13-28 August). In the 2 later trials, steers selected herbage from spreading, rhizomatous plants rather than the more caespitose plant. The most preferred plant was a very rhizomatous, low growing form (Truscott and Currie 1987). This growth form had a greater proportion of leaves to stems than did the more caespitose type plants. Also, the rhizomatous plants had fewer culms and less culm stubble. The smaller basal area plants consisted of very tight clumps of grass which had many tall, erect seed culms. After culms were grazed and clipped, residual crowns had an area in the center of plants with dry, stiff stubble which tended to limit growth of new material to the periphery of the plant. Cattle avoided grazing too closely to this stubble during the trials. Also, the steers avoided grazing within plants which had many, tall seedheads even though there were fresh, green leaves below. Murray (1984) reported that sheep also avoided plants as the number of seedstalks increased. His research covered 14 different grasses, including an RS hybrid selection. Because of this avoidance, "wolf plants" are formed in many of the bunchgrass species (Stoddart et al. 1975). Consequently, in our trials, the "type" of plant available to steers in later trials, when dry and fresh herbage were intermixed, appeared important in the selective grazing process on the hybrids and may have been reflected in the relationship between basal area, height variables, and bite counts.

Generally, correlations were low between most of the gross carbohydrate assays and bite count. Total nonstructural carbohydrates (TNC) were negatively correlated with bite counts over all trials. The majority of the relationships for TNC, total soluble carbohydrates (TSC), and reducing sugar extracts with bite counts were negative. These observations are opposite the findings of Bland and Dent (1964), but were comparable to those of Burton et al. (1964). Burton et al. (1964) encountered little variation among plants in TNC and TSC but substantial differences in animal preferences. Arnold and Dudzinski (1978) suggested several problems associated with the use of a gross indicator such as soluble carbohydrates. Depending upon the variety of forage and its carbohydrate make-up, these analyses produce a wide range of monoand polysaccharides and their derivatives, all of which vary in taste

Table 3. Mean percent fructose in water and acid extracts, mean amounts of total extract sugar and cell wall sugars ( $\mu$ g/ml) in high and low ranked bite groups of RS hybrids, trials 1 to 4.

\begin{tabular}{|c|c|c|c|c|c|c|c|c|}
\hline \multirow{3}{*}{$\begin{array}{l}\text { Rank } \\
\text { Groupl }\end{array}$} & \multicolumn{4}{|c|}{ Fructose, $\%$ of Total Sugars } & \multirow{2}{*}{\multicolumn{2}{|c|}{ Total extract ${ }^{2}$ sugars, $\mu \mathrm{g} / \mathrm{ml}$}} & \multirow{2}{*}{\multicolumn{2}{|c|}{ Cell Wall Sugars ${ }^{3} \mu \mathrm{g} / \mathrm{ml}$}} \\
\hline & \multicolumn{2}{|c|}{ Acid } & \multicolumn{2}{|c|}{ Water } & & & & \\
\hline & High & Low & High & Low & High & Low & High & Low \\
\hline \multicolumn{9}{|c|}{ Trial-Pasture: } \\
\hline $1-1$ & 25 & 22 & 23 & 19 & .64 & .69 & .31 & .39 \\
\hline $1-2$ & 25 & 28 & 17 & 15 & .61 & .64 & .45 & .35 \\
\hline $2-1$ & 22 & 23 & $21^{*}$ & $29^{b}$ & .75 & .81 & .34 & .40 \\
\hline $2-2$ & 24 & 26 & 29 & 27 & $.50^{*}$ & $.65^{b}$ & .32 & .42 \\
\hline 3-1 & $31^{\circ}$ & $40^{b}$ & 30 & 30 & $.76^{\mathrm{a}}$ & $.98^{\mathrm{b}}$ & .38 & .28 \\
\hline $3-2$ & $29^{a}$ & $38^{b}$ & 24 & 24 & .98 & .96 & .24 & .24 \\
\hline 4-1 & 45 & 48 & 29 & 31 & 1.13 & 1.29 & .20 & .21 \\
\hline $4-2$ & 41 & 42 & 28 & 26 & .84 & .87 & .27 & .26 \\
\hline
\end{tabular}

IPreference rank for high $(n=10)$ and low $(n=10)$ plants.

2Includes mannose, glucose, arabinose, xylose, rhamnose.

Includes arabinose, xylose, rhamnose.

Within rows and categories, rank group mean with unlike superscripts significantly differ $(\mathbb{P}<0.05)$. 
Table 4. Spearman's correlation coeficlents of bite count wh free-sugar and other selected variables from 1981 trials, $\mathrm{n}=20$.

\begin{tabular}{|c|c|c|c|c|c|c|c|c|}
\hline \multirow[b]{2}{*}{ Bites With: } & \multicolumn{8}{|c|}{ Trial-Pasture } \\
\hline & $1-1$ & $1-2$ & $2-1$ & $2-2$ & $3-1$ & $3-2$ & $4-1$ & $4-2$ \\
\hline $\begin{array}{l}\text { Height, cm } \\
\text { Basal areal } \\
\text { Phenology score }\end{array}$ & $\begin{array}{l}-.36 \\
.67 * \\
-.44^{*}\end{array}$ & $\begin{array}{l}-.31 \\
.85^{*} \\
-.83^{*}\end{array}$ & $\begin{array}{l}.61 * \\
.16 \\
.17\end{array}$ & $\begin{array}{c}.65^{*} \\
.11 \\
-.61^{*}\end{array}$ & $\begin{array}{c}.17 \\
.82^{*} \\
-.23\end{array}$ & $\begin{array}{r}.85^{*} \\
.88^{*} \\
-.56^{*}\end{array}$ & $\begin{array}{l}.41 * \\
.82 \\
.00\end{array}$ & $\begin{array}{r}.69^{*} \\
.86^{*} \\
-.49^{*}\end{array}$ \\
\hline $\begin{array}{l}\text { Percent fructose, acid } \\
\text { Total sugar } \\
\mathrm{TNC}^{2}\end{array}$ & $\begin{array}{l}-.37 \\
-.33 \\
-.62\end{array}$ & $\begin{array}{r}-.01 \\
.22 \\
-.35\end{array}$ & $\begin{array}{r}-.27 \\
.09 \\
-.43^{\star}\end{array}$ & $\begin{array}{l}.18 \\
-.53^{*} \\
-.54^{*}\end{array}$ & $\begin{array}{c}.06 \\
-.56^{*} \\
.14\end{array}$ & $\begin{array}{c}.02 \\
-.42^{*} \\
-.68^{*}\end{array}$ & $\begin{array}{r}.00 \\
.05 \\
-.37\end{array}$ & $\begin{array}{c}.48^{*} \\
.03 \\
-.43^{*}\end{array}$ \\
\hline $\begin{array}{l}\text { Nitrogen, \% } \\
\text { Silica, \% } \\
\text { RUID }\end{array}$ & $\begin{array}{r}.45^{*} \\
-.02 \\
.27\end{array}$ & $\begin{array}{r}.06 \\
-.40^{*} \\
.66^{*}\end{array}$ & $\begin{array}{r}.21 \\
-.38 \\
.54^{*}\end{array}$ & $\begin{array}{l}-.05 \\
-.54^{*} \\
.47^{*}\end{array}$ & $\begin{array}{c}.52 \\
-.22 \\
.39\end{array}$ & $\begin{array}{l}.60^{*} \\
.20 \\
.25\end{array}$ & $\begin{array}{l}.32 \\
.43^{*} \\
.08\end{array}$ & $\begin{array}{c}.60^{*} \\
-.05 \\
.46^{\circ}\end{array}$ \\
\hline Leaf score & $-.69 *$ & $-.59 *$ & .17 & $-.71 *$ & -.36 & -.17 & -.09 & $-.56^{\circ}$ \\
\hline
\end{tabular}

1 Basal area $=$ width $(\mathrm{cm}) \times$ length $(\mathrm{cm})$ of plant base or crown.

2TNC = total non-structural carbohydrates.

${ }^{3}$ RIUD = rumen in vitro digestibility.

*Significant, $P<0.05$.

from bitter to quite sweet. Another problem was differences inherent in stereoisomers of the same compound and the effect they have on taste characteristics.

Relationships of cellulase and rumen in vitro digestibilities to bite counts were considered important $(r>0.60)$ in trial 1, pasture 2, but not in other trials (Table 2). This was the only trial where plant phenology reached an advanced stage (Table 1) and indicated that digestibility could be an important influence on the consumption of these plants as they mature. However, rank-order correlations of cellulase and rumen digestibilities were significant $(P<0.01)$ between the 2 methods over the 4 trials. Values ranged from 0.54 to $0.74, n=46$. The cellulase technique consistently had a better correlation with bites than the rumen in vitro method.

\section{Sugar Relationships}

Percent fructose from the acid extract tended to increase from trial 1 to trial 4 but the percent fructose in water extract did not show a distinct trend (Table 3). The only significant differences between the 2 preference rank groups were from trial 3, pastures 1 and $2(P<0.05)$. The lower ranked plants $(n=10)$ had a significantly higher percentage of fructose in water extract $(P<0.05)$ than the top ranked plants $(n=10)$. Because of the sweetness of fructose, the opposite would have been expected. In trial 2, pasture 1, the lower bite count group also had a higher percentage fructose $(P<0.05)$ in the water extract. Cattle have been shown to prefer and be quite sensitive to sweet tastes (Goatcher and Church 1970) and would have been expected to select for fructose if indeed a relationship existed. This was not the case.

As shown in Table 3, most of the sugars present other than fructose, glucose, and sucrose are cell wall sugars. The total sugar category includes glucose, mannose, and the cell wall sugars. For total sugars, trial 3 , pasture 1 and trial 2 , pasture 2 were the only cases where a significant $(P<0.05)$ difference was found between ranked groups. Total sugars were greater in the low preference group than in the high preference group. These results of higher sugar concentrations in the less preferred plants support findings for TNC and TSC but were not consistent enough across trials to be valuable in predicting bites. In general, detailed analysis of the carbohydrates to their individual component sugars did not substantially increase our understanding of how carbohydrates affect palatability of RS hybrid plants. However, the analysis did indicate that a higher percentage of fructose, which is perceived as a very sweet sugar, had a negligible and in fact negative impact on cattle preference for the hybrid grasses.

Rank-order correlations of bites and several variables on the same 20 plants from each trial that were analyzed with the sugar data are shown in Table 4. The highest correlations were with the basal area during the last 2 trials and on both pastures were $0.82,0.88$, 0.82 , and 0.86 , respectively. Other variables whose correlations were considered biologically important were nitrogen, height, phenology, leaf score, and rumen digestibility. However, the relationships of these variables over trials and pastures were inconsistent and did not appear to be important factors in influencing bites.

\section{Regression Prediction Equations}

Subsets analyses were conducted on chemical, morphological and bite counts to develop the best prediction equations for each trial using all possible subset combinations. Variables from the 2 "best" equations based on Mallow's $C p$ values for each trial are shown in Table 5. Basal area was the dominant contributor in a majority of the equations and had consistently significant " $t$ " values. Other major contributors were height, phenology, and leaf

Table 5. Multiple regresion variables and Mallow's $C_{p}$ values from all posdible subsets analysis for "beat" fit equations; trials 1 to 4, pastures 1 and 2, $1981, \mathrm{n}=46$.

\begin{tabular}{|c|c|c|c|}
\hline Trial/Pasture & Equation = Variable(s) & Subset $R^{2}$ & Mallow's Cp \\
\hline $1 / 1$ & 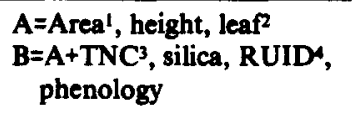 & $\begin{array}{l}0.63 \\
0.71\end{array}$ & $\begin{array}{l}12.5 \\
5.08\end{array}$ \\
\hline $1 / 2$ & $\begin{array}{l}A=\text { Area phenology, RUID } \\
B=A+\text { silica }\end{array}$ & $\begin{array}{l}0.65 \\
0.65\end{array}$ & $\begin{array}{l}0.23 \\
0.79\end{array}$ \\
\hline $2 / 1$ & $\begin{array}{l}A=\text { Height, RUID, ash, area } \\
B=A+\text { silica }\end{array}$ & $\begin{array}{l}0.43 \\
0.46\end{array}$ & $\begin{array}{l}3.46 \\
2.57\end{array}$ \\
\hline $2 / 2$ & $\begin{array}{l}A=\text { Area, height, ash, leaf } \\
B=A+T N C \text {, silica, rumen }\end{array}$ & $\begin{array}{l}0.47 \\
0.53\end{array}$ & $\begin{array}{l}8.07 \\
5.08\end{array}$ \\
\hline $3 / 1$ & $\begin{array}{l}\text { A=Nitrogen, area, RUID, } \\
\text { phosphorus } \\
B=A+\text { leaf }\end{array}$ & $\begin{array}{l}0.61 \\
0.61\end{array}$ & $\begin{array}{l}1.83 \\
2.35\end{array}$ \\
\hline $3 / 2$ & $\begin{array}{l}\text { A=Nitrogen, area, height, } \\
\text { leaf } \\
B=A+\text { phenology, TSC }\end{array}$ & $\begin{array}{l}0.74 \\
0.76\end{array}$ & $\begin{array}{l}5.20 \\
4.50\end{array}$ \\
\hline $4 / 1$ & $\begin{array}{l}A=\text { Nitrogen, area, silica } \\
B=A+\text { cellulase }^{6}\end{array}$ & $\begin{array}{l}0.60 \\
0.61\end{array}$ & $\begin{array}{l}-0.32 \\
-0.10\end{array}$ \\
\hline $4 / 2$ & $\begin{array}{l}\mathrm{A}=\mathrm{A} \text { Area, height, phenology, } \\
\text { moisture } \\
\mathrm{B}=\mathrm{A}+\mathrm{TSC}+\text { leaf }\end{array}$ & $\begin{array}{l}0.79 \\
0.81\end{array}$ & $\begin{array}{l}7.48 \\
5.12\end{array}$ \\
\hline
\end{tabular}

'Area = basal area, calculated as the product of width and length measures. 2Leaf = leaf score, 1-9 scale, droopy to erect structure, respectively. ${ }^{3} \mathrm{TNC}=$ total non-structural carbohydrates.

${ }^{4}$ RUID = in vitro rumen digestibility.

sTSC = total soluble carbohydrates.

-Cellulase $=$ in vitro cellulase digestibility. 
score. The coefficients of determination $\left(R^{2}\right)$ of 0.43 and 0.47 in trial 2 were lower than in other trials $\left(R^{2} 0.60\right.$ to 0.81$)$. These differences were likely caused by small differences in animal preferences between plants as was illustrated by the reduced range in bite counts between the most and least preferred plants at this time (Truscott and Currie 1987). Trials 3 and 4, for both pastures, were fairly uniform with regard to the variables which occurred in the "best" prediction equations. Basal area of the plant was the most important variable in the prediction equations and had an $R^{2}>0.70$ over all 46 clonal lines.

A regression analysis was also made on the high and low ranked plants from each trial $(n=20)$ with the individual sugar data (Table 6). Trial 2 again had the lowest $\boldsymbol{R}^{2}$ values, but individual sugars

Table 6. Multiple regresion variables and Mallow's Cp values from all possible subsets analysis for "best fit" equations; trials 1 to 4, pastures 1 and 2, 1981, $n=20$.

\begin{tabular}{|c|c|c|c|}
\hline Trial/Pasture & Variable (" $t "$ value) & Subset $R^{2}$ & Mallow's Cp \\
\hline $1 / 1$ & $\begin{array}{l}\text { TSC }^{1}(-1.95), \text { height }(-2.19) \\
\text { area }^{2}(4.04), \text { phenology }(-1.86) \text {, } \\
\text { leaf }(-3.10)\end{array}$ & 0.79 & -0.74 \\
\hline $1 / 2$ & $\begin{array}{l}\text { RUID (1.95), area (3.21), } \\
\text { phenology }(-1.91), \text { leaf }(1.65)\end{array}$ & 0.81 & 1.30 \\
\hline $2 / 1$ & $\begin{array}{l}\text { PFRUAs }(-2.74), \text { RUID }(4.35) \\
\text { moisture }(3.62), \text { area }(1.69) \\
\text { phenology }(-3.02)\end{array}$ & 0.73 & 0.77 \\
\hline $2 / 2$ & $\begin{array}{l}\text { PFRUA }(-3.20) \text {, TSUG } \\
(-2.50) \\
\text { TNC }(-2.72) \text {, silica }(-3.07) \\
\text { phenology }(-1.41)\end{array}$ & 0.75 & 2.96 \\
\hline $3 / 1$ & $\begin{array}{l}\text { TSUG (-3.99), TNC }(-2.44) \\
\text { RUID }(1.70), \text { area }(4.73)\end{array}$ & 0.81 & -0.07 \\
\hline $3 / 2$ & $\begin{array}{l}\text { Nitrogen (1.52), area (6.41), } \\
\text { phenology }(-4.10) \text {, leaf }(1.98)\end{array}$ & 0.87 & 1.87 \\
\hline $4 / 1$ & $\begin{array}{l}\text { Phosphorus }(2.96) \text {, silica }(2.86) \text {, } \\
\text { moisture }(-1.70) \text {, area }(6.47) \text {, } \\
\text { phenology }(-2.83) \text {, } \\
\text { leaf }(-1.84)\end{array}$ & 0.85 & 2.01 \\
\hline
\end{tabular}

ITSC = total soluble carbohydrates.

2Area = basal area calculated from length and width measurements.

${ }^{3}$ Leaf = leaf score, 1-9 scale, droopy to erect structure, respectively.

4 RUID = in vitro rumen digestibility.

sPFRUA = percent fructose in acid extract.

6TSUG = total sugar in acid extract.

TTNC = total non-structural carbohydrates.

accounted for $70 \%$ of the variation in bite counts. The best equations for each trial from this data set and the associated " $t$ " values for each variable are presented in Table 6. Basal area alone often had an $\boldsymbol{R}^{2}$ of 0.70 or greater. Except for phenology and basal area, variables most dominant in these equations were unique and did not frequently appear elsewhere.

The importance of basal area may be explained by 2 lines of thought. The first assumes that basal area is a measure of the amount of available herbage. This was the situation in later trials where quantity of herbage available for consumption could have been the limiting factor in the determination of bites much more than some qualitative aspect of the grass plants. This appears reasonable in view of the fact that regrowth in these later trials was much reduced with an average of $35 \mathrm{~cm}$ compared to earlier trials averaging $42 \mathrm{~cm}$. Although this may explain some of the importance of area as a prediction variable, it cannot be the only explanation. Observations and bite count data indicate some plant lines were relatively untouched at the completion of grazing trials and required clipping to lower their height to $10 \mathrm{~cm}$. Grazing did not occur to the point where the animals physically could not obtain additional plant material.

A second explanation for the importance of basal area in the regression equation involves the presentation of a favorable plant canopy to the animal for grazing. Typically, preferred plants were of a similar growth form. A close correlation existed between growth scores and width and length measurements. Preferred plants tended to be those of low stature $(<50 \mathrm{~cm})$, loosely bunched, and of a rhizomatous "type" that matured more slowly than the other plants. These plants also tended to have fewer seed culms which after several clippings became somewhat of a physical obstacle to grazing.

A multiple regression analysis was conducted with 6 of the variables which occurred most often in the subsets analysis in an effort to develop 1 equation that could alone be used to account for selective preference differences. Trials 1 and 2 were substantially different from 3 and 4 for the reasons described previously. Thus, the regression used data from only trials 3 and 4 . The variables plant basal area, nitrogen, phenology, leaf score, height, and rumen digestibility produced the regression equation:

$$
\begin{aligned}
Y=326.9 & +67.6 x_{1}-1.6 x_{2}+.44 x_{3}-6.9 x_{4}-1.3 x_{3}-4.4 x_{6} \\
\text { where: } & x_{1}=\text { nitrogen, } x_{2}=\text { phenological score, } x_{3}=\text { basal area, } \\
x_{4} & =\text { leaf score, } \\
& x_{6}=\text { height and } x_{6}=\text { rumen digestibility. } \\
Y & =\text { estimated number of bites. }
\end{aligned}
$$

In this analysis, basal area accounted for $54 \%$ of the complete model's $R^{2}$ of 0.72 and must be considered the primary variable affecting the number of bites taken per plant.

\section{Conclusion}

It was impractical to develop one prediction equation to explain animal preferences for hybrids over the entire growing season. Variables important in the animal preference selection process for the RS hybrid plants early in the grazing season (Trial I) included basal area, height, phenology score, leaf score, silica content, and rumen digestibility. Relevant relationships in trial 2 (June 15 to July 15) were unique and many of the significant correlations measured earlier disappeared. At this time, differences between clonal hybrid lines were minimal both chemically and morphologically and when differences were minimal, individual sugar composition became a dominant variable with respect to bite counts. Greater fructose content in the individual hybrid plants had a negative effect on the number of bites taken, and percent fructose in an acid extract and phenology were the only variables that consistently appeared in a prediction equation at this time. The most dominant factors affecting bites on both pastures in trials 3 and $4(n=184)$ were incorporated into a general prediction equation. An $R^{2}$ of 0.52 was produced and the importance of the relationships between factors such as basal area, height, nitrogen, leaf score and the carbohydrates were defined. These results showed selection should be made for plants of a specific growth "type" which allows easy access to green plant material by the animals and remains favorable to be grazed for an extended period of time. Additionally, management of plants by season of growth and the associated chemical status of these plants were shown to have a profound influence on selection preferences. These factors need to be considered in a breeding program used to select forages for livestock grazing.

\section{Literature Cited}

Arnold, G.W. 1981. Grazing behavior. p. 79-104. In: F.H.W. Morley (ed.), Grazing animals. World animal science, B1. Amsterdam, Elsevier.

Arnold, G.W., and M.L. Dudzinaki. 1978. Ethology of free-ranging domestic animals. Elsevier Scientific Publ. Co., Amsterdam, The Netherlands. 
Asay, K.H., and D.R. Dewey. 1981. Registration of Agropyron repens $X$ A. spicatum germplasms RS-1 and RS-2. Crop Sci. 21:351.

Bittnes, A.S., L.E. Harris, and W.F. Campbell. 1980. Rapid N-Methylimidizole-catalyzed acetylation of plant cell wall sugars. J. Agr. Food Chem. 28:1242-1245.

Bland, B.F., and J.W. Dent. 1964. Animal preferences in relation to the chemical composition and digestibility of varieties of cocksfoot. J. Brit. Grassl. Soc. 19:306-314.

Burton, G.W., F.E. Knox, and D.W. Beardsley. 1964. Effect of age on the chemical composition, palatability and digestibility of grass leaves. Agron. J. 56:160-162.

Chapman, R.F., and W.M. Blaney. 1979. How animals perceive secondary compounds. p. 161-198. In: G.A. Rosenthal and D.H. Janzen (ed.), Herbivores. Their Interaction with Secondary Plant Metabolites. Academic Press, New York.

Daniel, C., and F.S. Wood. 1971. Fitting equations to data. p. 86-115. Wiley-Interscience, Div. of Wiley \& Sons, New York.

Dewey, D.R. 1984. The genomic system of classification as a guide to intergeneric hybridization with the perennial Triticeae. p. 204-279. In: J.P. Gustafson (ed.), Gene manipulation in plant improvement. Plenum Publ. Corp., New York.

Fox, R.L., J.A. Siva, D.L. Plunkett, and D.Y. Teranishi. 1969. Soluble and total silicon in sugar cane. Plant and Soil 30:81-92.

Goatcher, W.D., and D.C. Church. 1970. Taste responses in ruminants. I. Reactions of sheep to sugars, saccharin, ethanol and salts. J. Anim. Sci. 30:777-780.

Goto, I., and D.G. Minson. 1977. Prediction of the dry matter digestibility of tropical grasses using the pepsin-cellulase assay. Anim. Feed Sci. and Tech. 2:247-253.

Krueger, W.C. 1972. Evaluating animal forage preferences. J. Range Manage. 25:471-475.
Martin, G.C. 1969. Measurement and significance of forage palatability. Proc. Nat. Conf. on Forage Qual. Eval. and Util., Nebraska Center for Continuing Education, p. Dl-D55.

Mellvanie, S.K. 1942. Carbohydrate and nitrogen trends in bluebunch wheatgrass, Agropyron spicatum, with special reference to grazing influences. Plant Physiol. 17:540-556.

Murray, R.B. 1984. Yields, nutrient quality, and palatability to sheep of 14 grass accessions for potential use on sagebrush-grass range in southeastern Idaho. J. Range Manage. 37:343-348.

Siezel, S.S. 1956. Nonparametric statistics for the behavioral sciences. McGraw-Hill Book Co., Inc., New York.

Smith, D., G.M. Paulson, and C.A. Raguse. 1964. Extraction of total available carbohydrates from grass and legume tissue. Plant Physiol. 39:960-962.

Somogyi, M. 1952. Notes on sugar determination. J. Biol. Chem. 195:19-23.

Stoddart, L.A., A.D. Smith, and T.W. Box. 1975. Range management. 3rd ed., McGraw-Hill Book Co., New York.

Sweeley, C.C., R. Bentley, M. Makita, and W.W. Wells. 1963. Gas-liquid chromotography of trimethylsilyl derivatives of sugar and related substances. J. Amer. Chem. Soc. 85:2497-2507.

Technicon Autoanalyzer II Methodolozy. 1977a. Digestion and sample preparation for the analysis of total Kjeldahl nitrogen/ phosphorus using the Technicon BD-20 block digestor. Industrial Method No. 369-75A/B.

Technicon Autoanalyzer II Methodology. 1977b. Starch in whole broth/BD. Industrial Method No. 364-75A. D/IV/b/3.

Tilley, J.M.A., and R.A. Terry. 1963. A two-stage technique for the in vitro digestion of forage crops. J. Brit. Grassl. Soc. 18:104-111.

Truscott, D.R., and P.0. Currie. 1987. Factors affecting dietary preferences for genotypes of a hybrid wheatgrass. J. Range Manage. 40:509-513.

Statement of Ownerahip, Management, and Circulation

(Act. of August 12, 1970, Sec. 3685, Title 39, United States Code)

1. Tille of Publication: Journal of Range Management

2. Date of Filing: September 9, 1988

3. Frequency of Issue: Bimonthly

4. Location of Office of Publication: 1839 York Street, Denver Colo. 80206

5. Location of General Business Office: Same

6. Name and Address of:

Publisher: Society for Range Management, 1839 York Street

Denver, Colo. 80206

Editor: Patricia Smith 1839 York Street,

Denver, Colo. 80206

Managing Editor: Peter V. Jackson III 1839 York Street,

Denver, Colo. 80206

7. Owner: Society for Range Management, 1839 York Street, Denver, Colo. 80206

8. Known Bondholders, Mortgagees, etc.: Wyatt Company, 1850

M St NW, \#700, Washington, DC 20036

9. For Completion by Nonprofit Organizations Authorized to Mail at Special Rates: The purpose, function, and nonprofit status of this organization and the exempt status for Federal income tax purposes have not changed during preceding 12 months.

10. Extent and Nature of Circulation
A. Total copies printed
B. Paid Circulation
1. Dealers, counter sales

$5,786 \quad 5,322$
2. Mail subscriptions
C. Total paid circulation
D. Free distribution
E. Total distribution
F. Copies not distributed

$\begin{array}{rr}0 & 0 \\ 4,996 & 5,108 \\ 4,996 & 5,108 \\ 8 & 8 \\ 5,004 & 5,116 \\ 782 & 206 \\ 5,786 & 5,322\end{array}$

Avg. for issue nearest
12 months filing date

I certify that the statements made by me above are correct and complete.-Peter $V$. Jackson, Managing Editor. 